\title{
The Development of Self- Helping Model for Poverty Alleviation on the Productive Poor Group
}

\author{
MG. Westri Kekalih Susilowati, Angelina Ika Rahutami, and A. Rachmad Djati Winarno
}

\begin{abstract}
There have been so many effort have been done to reduce poverty. The poor has decreased. However, it is still remain vulnerable. The existence of economic turmoil, such as crop failure and rising fuel prices would quickly raise up poverty. The empowerment of the poor is done uniformly and pay less attention to the character of the poor, especially their the social psychology character. High economic growth often ignores the poor and marginalized. Therefore, inclusive growth can play an important role in alleviating poverty.

This research is supposed to identify the social phsycology character of the productive poor, local wisdom related to poverty reduction, as well as develop a model of self-helping program for poverty alleviation.

This study identified two groups of poor who has different social psychology character. The first group is the group of the poor who tend to accept poverty as destiny. This group considers that education is not important and subsistence work. This group tend to be found in rural which has low levels of mobility, and the people tend to be homogeneous. Secondly, the groups of poor who believe that poverty can be changed. They argue that the key factor to get out of poverty is education. Most of them set aside part of their income to live better in the future. This group tend to be found in urban which has high levels of mobility, and people are more likely heterogeneous
\end{abstract}

Index Terms-Empowerment, inclusive growth, productive poor, poverty alleviation, social phsycology.

\section{INTRODUCTION}

Poverty is one of the problems faced by provinces in Indonesia, including Central Java. According to Indonesian Statistic's data, the number of poor in Central Java in March 2011 amounted 5,107 million people (15.76 percent to total population), much less than in March 2010. The poor in Central Java has decreased, however it is still remain vulnerable. The existence of economic turmoil, such as crop failure and rising fuel prices would quickly raise up poverty.

The high growth of economy sometimes ignoring the poor and marginalized people. Therefore, high growth of economy sometimes resulting an increase in inequality [1]. The Increasing in inequality may have implications such as a

Manuscript received November 19, 2013; revised February 20, 2014 This research was supported by SIMLITABMAS, Directorate of Higher Education, Department of Education of the Republic of Indonesia under Universities's Prime Research Grant 2013.

MG. Westri Kekalih Susilowati and Angelina Ika Rahutami are with the Faculty of Economics and Business Soegijapranata Chatolic University Semarang, Indonesia (email: mgwestrie@yahoo.com, a_rahutami@yahoo.com)

A. Rachmad Djati Winarno is with the Faculty of Phsycology Soegijapranata Chatolic University Semarang, Indonesia (e-mail: rdwinarno@yahoo.com). raising in the rate of poverty, political instability and social instability as well as lower growth itself. Then, Central Java implements pro-poor, pro-jobs and pro-growth to address poverty. When the inequalities occur, it could mean that development does not in line with the concept of inclusive growth. Reference [2] shows the main source for inclusive growth and poverty alleviation is the field of productive and decent employment, social security and increasing the capability of the basic needs of the community. It is not enough to make inclusive growth materialized, if the poverty alleviation just rely on aid or granting and so do the empowerment of the poor is done uniformly. It is important to consider the characters of the poor, especially the social psychology character of the poor in order to obtain a comprehensive model of poverty alleviation.

\section{LITERATURE REVIEW}

\section{A. Poverty and Poverty Alleviation Program}

The definition of poverty refers to a condition of helplessness in meeting the needs. Poverty is a multidimensional problem. Based on the literature, there are several definitions of poverty, among others are:

1) Absolute poverty; absolute poverty refers to definition that the poor are those whose income is below the poverty line. Common measure used is the size according to the World Bank, the U.S. \$ 1 per day and U.S. \$ 2 per day.

2) Relative poverty; poverty refers to the condition of the distribution of income in society. Thus, the poor are always present in the life

3) Structural poverty; structural poverty refers to poverty caused by the structure or governance of community life.

4) Cultural poverty, cultural poverty is the poverty is caused by factors such as customs and culture (local culture).

Poverty is a problem that exist from earlier times. The government has made various efforts to reduce poverty. Some of the efforts made by the government are poverty alleviation program sponsored by the World Bank at the sub-district and urban poor, Kredit Usaha Tani/KUT (Credit for Famer), beras untuk orang miskin/ RASKIN (rice for the poor), Jaring Pengaman Sosial/JPS (the social safety net), Kartu GAKIN (poor family card), education for poor students, Kredit Usaha Rakyat/KUR (the People's Business Credit), P2KP, Bantuan Langsung Tunai/BLT (direct cash assistance), Program Nasional Pemberdayaan Masyarakat Mandiri/PNPM Mandiri (National Program for Community Empowerment) and so forth.

It is seemed that poverty rate does not change. This 
condition does not reflect that government has failed to reduce poverty. However, there is one thing that can be examined in the poverty alleviation programs. Poverty alleviation programs have tended to put "the poor" as objects. There are some weaknesses in the poverty alleviation program [3] , those are: (1) tend to be oriented on economic aspects, yet multidimensional, (2) charity nuanced (generosity) and not productivity nuance, (3) the poor becomes object instead of the subject, (4) the position of the government as an authority rather than a facilitator. Reference [4] expressed the need for a new paradigm in the alleviation of poverty, which emphasizes "what is owned by the poor" instead of "what is not owned by the poor".

\section{B. Inclusive Growth}

In order to achieve the highest economic growth, some issues of income distribution sometimes be ignored. As a result, the income gap in society become wider. There is a group of people who are not able to access process and outcomes of development. Hence, development planning should pay attention to the problems of poverty, including the distribution of income in society. The high growth of economic and poverty are inseparable.

Inclusive growth is the growth for all. This concept refers to a sustainable economic. In this concept, the result of development can be enjoyed by or distributed to all segments of society, including the poor and marginalized, either now or future. Thus, there are two main points in inclusive growth, (1) Inclusion (participation), which means that there is a diffusion of opportunities for all. Inclusion growth also provides opportunities to those excluded in the current growth, and (2) sustainable growth, which means that the process of growth does not stop. The growth of the economy occurring now to the future.

Inclusive growth is an effective strategy for reducing poverty due to poverty alleviation which is based only on absolute income sometimes ignore some issues of inequality and risks. Instead, inclusive growth strategy focused on creating opportunities and ensuring equal access. Equal access to opportunity can be a basic instrument to increase human capacity, including the poor which has workforce as a major asset. In general, the focus on inclusive growth is the process improvement of the opportunities that will be effective to reduce poverty, and inequality.

\section{Productive Poor}

President Susilo Bambang Yudhoyono issued Presidential Decree No. 15 Year 2010 on the Acceleration of Poverty Alleviation. The main purpose of the regulation is to reduce poverty rate to $8-10$ percent by the end of 2014 . It is mentioned "productive poor" term in this Presidential Decree. "Productive poor" is defined as poor families who have no source of income and neither ability to meet basic needs or people who have a source of livelihood, but can not meet basic needs for decent humanity. Productive poor is also defined as the poor families who have a decline in income and welfare or having income discontinuation. Based on the age grouping, productive poor are poor people aged 15-55 years. This group is then used as a focus of productive poor poverty alleviation.

\section{The Culture and Poor}

Society can not be separated from culture consciously or not influential in their thinking and behavior [5]. Poor people who live in rural areas could have been influenced by the character of rural communities as well as a close relationship and a strong bond strict social control, mutual assistance, and the pattern of a simpler life. Similarly, the heterogeneous character of the city and do not put close relationships and the existence of a higher tolerance will affect the lives of the urban poor [6].

An expert of Social learning theory, Albert Bandura, argued that human behavior can not be separated from the influence of the individual and the environment [7]. In these cases, the relationship between the environment, the individual, and their behavior is reciprocal (mutual). This theory assumed that the individual productive economic activities can not be separated from the environment in which the individual lives and personal characteristics of the individual concerned. This means that these three elements, namely environmental, individual, and behavior interplay. Environment, both social and physical, provide a variety of possibilities and limitations for individuals to behave. Such behavior is in turn also affects the individual concerned and the environment in which he lives.

\section{E. Motivation and Self-Efficacy}

Condition of a person who is perceived as lacking by the person will lead to the need. This is called by Maslow as deficiency needs. Deficiency needs include the needs for survival, safety, love, belongingness, and esteem. Another being need is the need for self-actualization, the need to "be". Human needs are hierarchical. People would meet the needs from the most basic needs, namely the need to survive (survival). Survival needs is physiological. Hence, it can be said that the poor people struggling more to meet this basic needs.

The needs of the individual bring impetus to undertake activities to meet those needs. It's called motivation. Motivation is the drive that makes people behave in a certain way. It could be mean that the behavior of the poor to overcome poverty is also is also not be separated from motivation. Various studies have shown that a strong motivation will affect the performance and achievements of businesses and individuals as well as groups [8].

In attempting to come out from conditions that are less (which raises the need for) Individuals often face a variety of constraints, both from inside and outside individual. Constraints from the individual include the ability to and willingness of the individual and other individual factors. Constraints also come from outside himself, including from their own group. This is called the motivational gravity [9]. Motivational refers to how strong the gravity of environment supports or inhibits individual members of the group to transform itself and thus stands out compared to the other member in group. Motivational gravity can be derived from each other (peer) or superiors. Poor peer are all the poor all member of the poor community itself. Community leaders and people who are socio-economically better able to function as leader. Motivational gravity will affect the success of the business and who tried to come out from the current condition. 
Bandura [10] introduced what he called self-efficacy, i.e., the individual's perception of his ability to behave in a certain way in a particular situation. Self-efficacy plays a role in some specific behavior, both in health and social relations. Self-efficacy plays a role in the various stages of a person's behavior, began from the emergence of the idea, behavior planning to the actual behavior as well as the recovery process when there is a failure in behavior. In conjunction to the effort of the poor, the behavior means the concrete behavior to come out from the poor conditions endured today. The extent to which people will seek also depends on how people see themselves, whether he is capable or not capable to come out from the poor condition.

\section{RESEARCH METHOD}

\section{A. Research Objectives}

The problem of poverty is multi-dimensional so it is not quite solved simply by granting subsidies or cash assistance to the poor. One of the best ways to come out of poverty is the empowerment of self. Therefore, the general purpose of this research is to develop a model of self-empowerment or self-helping program to come out of poverty.

\section{B. Beneficiaries}

This research has some beneficial as follows:

1) The overall study is expected to contribute in improving the welfare of the community, particularly through the expansion of equal opportunity for all people to take a part in and enjoy the result of development, especially for the poor and marginalized people.

2) Donor: This study is expected to be a reference to address the poverty alleviation.

3) Government: This study is expected to be a guidelines in formulating policies to address the poverty alleviation.

4) Academicians: This study is expected to enrich reference and knowledge that concern with poverty alleviation.

\section{Sample and Population}

This research is designed as exploratory research. This research aim to map the multidimensional character of the poor as well as the nature of poverty. The main character that will be explored are the potencies of the poor as a basis for developing a model that empowers the group itself. This research is multidimensional because it will explore some of positives character, the economic potential of the poor, local wisdom which includes economic, socio-cultural and ecological.

The research was conducted in Wonosobo and Klaten regency which are pockets of poverty in Central Java. Determination of the regencies are also based on the poverty gap index and poverty severity index. Wonosobo and Klaten regency are regencies that has the highest poverty gap index and poverty severity index in Central Java. While the respondents in this study will be taken by convenience sampling technique

\section{Data}

In order to achieve the research objectives well, in this study used both primary and secondary data. Primary data include positive characters, potential of economic, cultural (customs), expectation, local wisdom and the role of government. The main source of primary data is poor groups. While the secondary data includes data associated with poverty such as growth poverty, poverty gap index, poverty severity index as well as the various programs and policies of poverty alleviation.

In order to obtain the required data, this study used some data collecting technique, that is:

1) Documentation. This method is used to map the current conditions of poverty, projections and identify the various programs that have been undertaken by the government to reduce poverty.

2) Interviews (face to face interview). Interviews is used to obtain data from the primary target group of the positive characters, economic potency, cultural (customs), local wisdom as well as their expectations

3) Focus Group Discussion (FGD). FGD aims to conduct synchronization the various opinions of various related parties in poverty alleviation efforts such as community leaders, academia and government

\section{E. Analysis Technique}

This study uses analysis techniques qualitatively as well as quantitatively and includes several stages. The stages of research are as follows:

1) Conduct a preliminary study to map out the general conditions poor groups in Central Java, especially in the two selected districts.

2) Identify positive characteristics, economic potential and local wisdom in productive poor communities.

3) Model development. On the basis of the field studies and supported by theory of social psychology and economics, alternatives model of productive poor community empowerment are developed. Empowerment model that will be developed is self-helping model. A model that is expected to encourage the people by themselves and their own strength trying to come out of the shackles of poverty. .

\section{THE RESUlt AND DisCUSSION}

\section{A. Demographics Character of the Productive Poor in Klaten and Wonosobo Regency}

The following exposure presenting the demographics character of the productive poor groups in Wonosobo and Klaten Regency. Wonosobo Regency representing the productive poor in the rural areas. While Klaten Regency representing the productive poor in urban areas.

Most of the respondents has education up to elementary school (Sekolah Dasar/SD). In Klaten Regency, the number of respondents who passed the elementary school and below is 74.00 percent. Meanwhile, in Wonosobo Regency is 88.00 percent. Based on marital status, the majority of respondents are married and the head of household. This research also found that most of respondents have dependents from two to four people. Related to assurance issues, it is known that almost all respondents have health insurance (Assurance/JAMKESMAS). Usually, there are just one 
person who works for a living in a family.

Most respondents in Klaten have a job working alone status. Meanwhile, in Wonosobo regency is working alone and as a laborer. This may occur due to differences in economic structure. The Areas of research in Wonosobo Regency is the rural livelihoods where the most of the population are farmers. Meanwhile, the economic structure of Klaten Regency tends to trade. Comparing the amount of income to expenditure, this study shows that the average amount of expenditure equal relatively to the amount of income. The average of income and expenditure either in Klaten Regency and Wonosobo is Rp450.000, 00 to Rp493.000, 00 per month. Most of these families have experienced the condition in which the expenditure is greater than income. This budget shortfall is usually covered with the debt or asked for help from family that are considered capable.

\section{B. The Social Psychology Character of Poor}

One of the most important factors in the planning of poverty alleviation programs is knowing how the poor look at the poverty itself. This study reveals some issues related to the perspective of the poor to their poor conditions. The poor's perspective to their poor condition reflects their "social psychology" character. The Perspective on poverty in this study are detailed into some items such as how to measures of poverty, why are they poor? What will they do to come out of poverty? What programs are expected to come out of poverty? The following section describes the perspective of the poor to the detail items.

The majority of informants in the FGDs in both regency feel poor because their income does not meet the needs. Measurement of poverty is also based on the condition of building of the house. They feel poor because their houses are small, ugly and doesn't made of brick. They also feel poor because they do not have a steady job that can be a source of a regular income. Inability to pursue higher education or to send their children well also becomes ones among the reasons feel poor. In Wonosobo regency where the study area is the rural, they feel poor because they have just a small land for farming, or even have no rice fields and only a laborer.

There are many factors that are identified as the cause of someone to be poor. Those are:

\section{1) Education factors}

The main factors of poverty that was identified in this study is education factors. All informants presuppose that if he had the chance to get a higher education then surely the situation would be better, or not poor. Therefore, some of informants who already married and have kids try to send their children to go to school as high as possible.

\section{2) Cultural factors}

Cultural factors influence the emergence of poverty. In this study, there is a respondent who shared his experiences about the condition of poverty. The resource person had high school, and her husband is an undergraduate. In the beginning, her husband was working as a lecturer in Jakarta and Kalimantan (still honoree). However, eventually the opportunity to become a lecturer cannot be taken because his parents forbade him to go wander. The concept of "mangan ra mangan kumpul" / (weather eating or not, always together), still held by his parents. Because of it is forbidden by his parents, he started to open motorcycles repair business.

3) Destiny factors

Factors destiny as one of the causes of poverty implied in some of the statements as follows:

1) “....bagaimana ya?.....bagi saya seperti sudah digariskan oleh Yang di atas (Tuhan).... , saya dulu punya usaha salon, tetapi kena gempa......., sekarang mau buka lagi belum punya modal.....ya jadi miskin begini..." ("... How?....... for me, as was determined by the Its in the top (God) .... I have ever barber shop, but destroyed by an earthquake ......., now, I want to start again but do not have the capital yet ..... now, I am poor ... ")

2) “...menjadi miskin....ada faktor takdir....., sudah berusaha tapi ada-ada saja.......warungnya hancur lebur karena gempa....." ("... To be poor? .... my destiny, I have tried to come out but there is always a nuisance ...... my stall were completely destroyed by the earthquake ..... ")

3) “...........la pripun, sampun digariskan nggih dilakoni mawon....(mau apa lagi, sudah ditakdirkan ya dijalani saja......)".( What can I do? , to be the poor is my destiny, simply be lived.

\section{4) Behavioral factors}

There is one resource persons who admitted that he was poor was the result of consumptive behaviors. Previously, he was a shoe seller. He ran out of capital, because of his consumption behavior. He did not separate business finances to his private wealth. The resluts of shoe sales is used for consumption, especially cigarettes. In the end, the capital was eroded and depleted for consumption.

There are significant differences between the perspectives of the poor to the causes of poverty. Poor people in Klaten Regency stating that the main cause of poverty is the educational factor. Meanwhile, in Wonosobo Regency the poor tend to accept the poor conditions as destiny.

Perspective on poverty affects the ideals or the action plans and also his desire to strive out of the poor situation.

TABLE I: THE TYPES OF EFFORT TO COME OUT OF POVERTY (\%)

\begin{tabular}{lrr}
\hline \hline Effort Types & \multicolumn{1}{c}{$\begin{array}{l}\text { Klaten } \\
\text { Regency }\end{array}$} & $\begin{array}{l}\text { Wonosobo } \\
\text { Regency }\end{array}$ \\
\hline Switch to a better job & 11,63 & 18,18 \\
Looking for a Debt/finding financial aid & 37,21 & 57,58 \\
or working capital & & \\
start a business & 39,53 & 30,30 \\
Pursuing at least one of the family & 16,28 & 6,06 \\
member in higher education & & 15,15 \\
Others & 16,28 & \\
\hline \hline
\end{tabular}

Source: primary data, processed.

Starting a business and find financial aid to come out of the poor has been done by the majority of the poor in Regency Klaten and Wonosobo. Concerning with the efforts to come out of poverty by striving for at least one of the family member in higher education is mostly done by the poor in Klaten. It is in line with their thoughts about causes of poverty. The poor in Klaten Regency tend to see that the main cause of poverty is the educational factor. Meanwhile, the poor in Wonosobo regency tend to see that poverty is destiny (Table I). 
Starting a business and find financial aid to come out of the poor has been done by the majority of the poor in Regency Klaten and Wonosobo. Concerning with the efforts to come out of poverty by striving for at least one of the family member in higher education is mostly done by the poor in Klaten. It is in line with their thoughts about causes of poverty. The poor in Klaten Regency tend to see that the main cause of poverty is the educational factor. Meanwhile, the poor in Wonosobo regency tend to see that poverty is destiny.

Differences in the character of poverty can also be seen from the kinds of programs / assistance expected by the poor. The majority (60.87 percent) of respondents on the poor in Klaten expect productive programs/assistance such as working capital, tuition assistance or educational aid, and health aid. Respondents in Wonosobo regency tend to expect consumer goods such as food and house. As mentioned earlier, this study starts from the typology distinction as one of the factors that may cause differences in the character of poverty. This study proved that there are differences in the character of poverty. Nevertheless, this study would not generalize it into rural and urban poor character. Because, the perspective on a particular thing including poverty is affected by many factors such as culture, environment, accessibility region, the intensity of social interaction between the residents and with the community outside, historical background and so forth.

This study found two character of poverty, those are the poor people who are resigned to poverty (group A) and the poor people who want a better/prosperous life (group B). In detail, the group "A" has the properties:

- Accept poverty as the destiny,

- Tend to be apathetic,

- Less conscious of education,

- The Intensity of social interaction with the outside community is relatively low,

- Has a relatively homogeneous community (among others in terms of education level, economic status, livelihood, culture,

- Live in neighbourhoods with the public facilities and social facilities inadequate/limited,

- Facilities and infrastructure for mobility are relatively low, and

- Working for mere survival (subsistence). Detail of group "B" properties are:

- Argues that poverty is not the destiny, so it can be changed,

- Have confidence and eager for a better life,

- Conscious to education, education is the key out of poverty,

- Intensity of social interaction with the outside community is relatively high,

- Heterogeneous communities tend to have (among others in terms education level, economic status, livelihood, culture),

- Live in a neighbourhood with the general and social facilities are adequate,

- Facilities and infrastructure for mobility are relatively high.

- Allocate part of their income in order to live better in the future (saving up to raise capital, the budget allocated for education)

\section{Local Wisdom of Poverty Alleviation}

This study did not find any local wisdom that is directly related to the problems of poverty in Wonosobo Regency. However, like other Javanese, community in Wonosobo Regency has local knowledge "gotong royong" (mutual cooperation) and adherence to community leaders, especially religious leaders. Therefore, in designing poverty alleviation programs need to consider both the local wisdom.

In Klaten regency were found several local wisdom such as:

1) The awareness the rich to the poor relatives. The rich usually give relief to the poor to send their children for example.

2) "Ngenger", i.e., poor people entrust their children to the rich. There are two types of "ngenger". First, poor families entrust their children to the rich without the child should help with household work. Second, poor families entrust their children to the rich, doing household work, unpaid but schooled.

3) Institutionally, in the mosque or church has a special account to hold funds from the social community that is able to be distributed to the poor in the form of school aid or financial aid. In the church named "Tabungan Cinta Kasih" (love savings).

\section{The Development of Self-Helping Model Accordance to the Social Phsycological Character of the Poor}

Self-helping model can be interpreted as a model that emphasizes the role of individuals or communities to help or develop themselves by harnessing all the potential uses of the communities themselves or those around him. In a self-helping model, individuals or society has a major role in the development of themselves, without leaving cooperation to the other parties. To develop this model need a deeper understanding of the community itself.

This research was conducted on the "productive poor" at two locations that have different typology characteristic. Klaten Regency is a sample of the urban poor, while Wonosobo is the rural poor. As part of a community of a city (even though a small town) Klaten communities have more access to some facilities such as education, transportation, various forms of economic activity, health, and so forth than Wonosobo.

As described in the previous section, people with low education (Elementary School or lower) in Klaten Regency is not as much as Wonosobo. The magnitude access to education also allows people in Klaten to pursue a higher education than Wonosobo. It also indirectly influences the way of thinking about the importance of education. An adequate transportation facilities in terms of roads and other means of transportation (vehicle) allows people in Klaten have higher mobility than people in Wonosobo. This high mobility, in turn, allows for greater interaction to the more people as well as an opportunity for economic development efforts. Job availability also varied more in urban areas (Klaten) than in rural (Wonosobo). Wonosobo regency is the mountain slopes region. Most of the population lives from agriculture, either as farmer's owners, tenants, and farm labourers. Thus the jobs available are also more related to 
agriculture. Traditional agricultural activities, especially as farm labourers, particularly technical skills and physical demands, without ignoring the aspect of knowledge.

\section{COCLUSSION}

This study increasingly asserted the existence of differences in the social psychology character of the poor that is caused by differences in the natural environment, culture, social interaction, history, and a few other things. There are the poor who live in Therefore, in formulating poverty alleviation programs should be tailored to the main characters in each group.

Poverty alleviation program for the poor that have main characteristics accepting poverty as destiny, apathetic, less conscious education, and working for mere survival (subsistence); the program should be a program that is supposed to encourage a change of mind-set or paradigm of a more prosperous life, the need for self-development through education and that being poor is not destiny but can be changed. For the poor who believe that the poor condition can be changed (not destiny), eager for a better life, conscious education, and allocate some of its earnings for a better life (through education or capital accumulation), the program should be a program that is supposed to enhance the knowledge and ability of the poor to harness his potential and existing social capital

\section{ACKNOWLEDGMENT}

We would like to thanks to Dr. M. Sih Setija Utami. M.Kes., the head of Research and Community Service (LPPM) Soegijapratana Catholic University Semarang; Prof. Vincent Didiek WA and Dr. Bagus Wismanto for your for useful comments and inputs and Dr. Octavianus Digdo Hartomo., Akt and Dr. Ridwan Sanjaya for your beneficial comments; to all respondents, informants and enumerators for helping uas; and to those who indirectly contributed in this research, your kindness means a lot to us. Thank you very much

\section{REFERENCES}

[1] I. Ali, "Inequality and the imperative for inclusive growth in Asia," Chapter of Ínequality in Asia, in Key Indicators 2007, Asian Development Bank, pp. 1-12, 2007.

[2] I. Ali and H. H. Son, "Measuring inclusive growth," Asian Development Review, Asian Development Bank, vol. 24, pp. 11-31, 2007.

[3] A. Huraerah. (January 2, 2006). Poverty Reduction Strategy, Pikiran Rakyat. [Online]. Avaliable: http://www.pikiran-rakyat.com/cetak/2006/012006/02/teropong/0401. htm

[4] L. A. Samovar, R. E. Porter, and E. R. McDaniel, Communication between Culturels, Interpreting: Indri Margareta Sidabalok, Jakarta: Salemba Humanika, pp. 26, 2010.

[5] H. Hartomo and A. Aziz, Basic Social Sciences, Jakarta: Bumi Aksara, pp. 43-44, 2008.

[6] A. Bandura, "Social cognitive theory: An agentive perpective," Annual Review of Psycholgy, vol. 52, pp. 1-26, 2001.

[7] J. A. Colquitt, J. A. LePine, and R. A. Noe, "Toward an integrative theory of training motivation: A meta-analytic path analayisis of 20 years of research," Journal of Applied Psychology, vol. 85, pp. 678-707, 2000.

[8] S. C. Carr, M. MacLachlan, C. G. Zimba, and M. Bowa, "Managing Motivational Gravity in Malawi," The Journal of Social Psychology, vol. 135, pp. 659-662, 1995.
[9] A. Bandura, Self-Efficacy: The Exercise of Control, New York: W. H Freeman and Company, 1997, pp. 71.

[10] A. Banjo, "A review of poverty studies, drivers and redressive strategies in southern Africa," Journal of Sustainable Development in Africa, vol. 10, no. 4, pp. 1-30, 2009.

[11] N. L. Gage and D. C. Berliner, Educational Psychology, 3rd ed., Boston: Houghton Mifflin Company, 1984.

[12] National Network Enabling Self Help Movement (Enable), in Proc. NRLM workshop final, New Delhi, October 8, pp. 8-12, 2009

[13] Organization for Economic Co-Operation and Development (OECD), The Knowledge Economy Science, Technology and Industry Outlook, Paris: OECD, 1996.

[14] E. Suharto, Paradigma Baru Studi Kemiskinan, Media Indonesia, 10 September, 2003.

[15] A. Woolfolk, Educational Psychology, 9th ed., Boston: Allyn and Bacon, 2004.

[16] R. Schwarzer, (Ed.), Self-Efficacy: Thought Control of Action, Washington, Hemisphere Publishing Corporation, 1992.

[17] R. D. Winarno, Indonesian Adolecents Sexuality and Romantic Relationships, Ph.D. dissertation, Radboud Universiteit, Nijmegen, 2007.

[18] R. Schwarzer, "Self-efficacy in the adoption and maintenance of health behaviors: Theoretical approaches and a new model," in Self-efficacy: Thought Control of Action, Washington, R. Schwarzer (Ed.) Hemisphere Publishing Corporation, 1992

[19] P. M. Romer, "Endogenous technological change," Journal of Political Economy, vol. 98, no. 5, pp. 71-102, 1990.

[20] B. K. Sagnia, "Strengthening local creative industries and developing cultural capacityfor poverty alleviation," presented at the Sixth Annua Conference17-20 November 2005 Dakar, Senegal, 2005.

[21] J. Schaubroek, S. S. K. Lam, and J. L. Xie, "Collective efficacy versus self-efficacy in coping responses to stressors and control: a cross-cultural study," Journal of Applied Psychology, vol. 84, pp. 512-525, 2000.

[22] M. Woolcock, "Social capital in theory and practice: reducing poverty by building partnerships between states, markets and civil society," UNESCO, Working paper, pp. 20-38, 2002

[23] T. Yulianto, "Phenomenon poverty alleviation programmes in klaten district (District jotangan village case study bayat) (Thesis)," Graduate Master of Regional and City Development Engineering Diponegoro University, 2005.

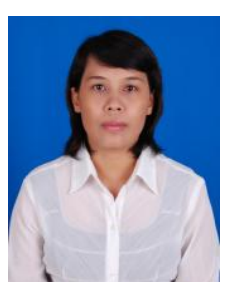

MG. Westri Kekalih Susilowati was born in Magelang-Indonesia, in April 1969. Her educational background is the undergraduate in the Faculty of Economis and Business, Gadjah Mada University, Yogyakarta, Indonesia in 1992 and the Faculty of Economis, Indonesia University, Jakarta, Indonesia in 2000. She is a lecturer in Facuty of Economics and Business Soegijapranata Chatolic Universitiy Semarang Indonesia. The field major is economics including macroeconomic, microeconomic, regional economic.

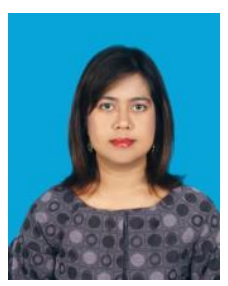

Angelina Ika Rahutami was born in Yogyakarta-Indonesia, in Februari 1968. Her educational background is the undergraduate was the Faculty of Economis and Business, Gadjah Mada University, Yogyakarta, Indonesia in 1991 and post graduate of Faculty of Economis and Business, Gadjah Mada University, Yogyakarta, Indonesia in1995 and doctoral of Faculty of Economis and Business, Gadjah Mada University, Yogyakarta, Indonesia in 2007. She is a lecturer in Facuty of Economics and Business Soegijapranata Chatolic Universitiy Semarang Indonesia. The field major is economics including macroeconomic, microeconomic, econometric, monetery.

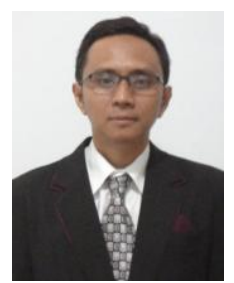

A. Rachmad Djati Winarno was born in Wonogiri-Indonesia, in Agustus 1961. His educationa background is the undergraduate in Departemen of Philosophy and Sociology of Education, Sanata Darma University, Yogyakarta, Indonesia in 1990 and the post graduate in De La Salle University, Manila, Phipilina in 1995 and the doctoral in Faculty of Phsycology, Radboud Universiteit, Nijmegen, Netherlands, in 2007. He is lecturer in Facuty of Phsycology Soegijapranata Chatolic Universitiy Semarang Indonesia. The field major is phsycology including social phsycology, guidance and counseling. 